Braithwaite, R. J. \& Olesen, O. B. 1982: Glaciological investigations at Qamanârssûp sermia. Field report 1979-1981 and appendix tables. Grønlands geol. Unders. Gletscher-hydrol. Meddr 82/2, 58 pp.

Braithwaite, R. J. \& Olesen, O. B. 1985: Ice ablation in West Greenland in relation to air temperature and global radiation. Z. Gletscherk. Glazialgeol. 20(1984), 155-168.

Olesen, O. B. 1981: Glaciological investigations at Qamanârssûp sermia, West Greenland. Rapp. Grønlands geol. Unders. 105, 60-61.

Olesen, O. B. \& Braithwaite, R. J. 1982: Glaciological investigations at Qamanârssûp sermia, West Greenland. Rapp. Grønlands geol. Unders. 110, 88-90.

\title{
Energy balance on outlet glaciers from the Inland Ice, West Greenland
}

\author{
N. Tvis Knudsen, O. Ottosen and L. M. Svendsen
}

As part of the GGU programme of hydropower investigations in West Greenland, energy balance measurements were made on Qamanârssûp sermia during the 1986 ablation season. The investigations are the continuation of a project in which Aarhus University has measured energy balances on Nordbogletscher, Johan Dahl Land, in 1981 and 1982 and on Qamanârssûp sermia in 1984 in collaboration with P. Clement and R. J. Braithwaite, respectively (fig. 1).

The main point of the programme was direct calculation of the ablation at the glacier surface from observations in the atmospheric boundary layer. Measured ablation was also used to calculate the residual part of the energy balance, as all elements were not determined. Lastly, the ablation was evaluated using variables chosen by correlation between easily measured climatic elements and the energy balance.

The measurements in Johan Dahl Land were made by Jens Peter Jensen and Ole Ottosen as part of a student thesis project. Ole Bendixen undertook field measurements in 1984 on Qamanârssûp sermia while Ole Ottosen and Lars Moeslund Svendsen carried out the field work in 1986.

\section{Johan Dahl Land}

Energy balance measurements were carried out in the middle lower part of Nordbogletscher about $800 \mathrm{~m}$ a.s.l. from mid-July to early September in both years. The energy balance station was situated over an ice surface which developed from a smooth to an undulating topography during the measuring period.

Net radiation was measured directly and the turbulent fluxes were calculated from measured vertical profiles of temperature, wind and humidity. The investigations were described by Jensen (1986) and Ottosen (1986).

Table 1 shows that radiation is generally the main source of ablation energy, although turbulent energy flux provides the main contribution during cyclonic weather. Despite this, Table 2 reveals the absence of a positive correlation between measured ablation and radi- 


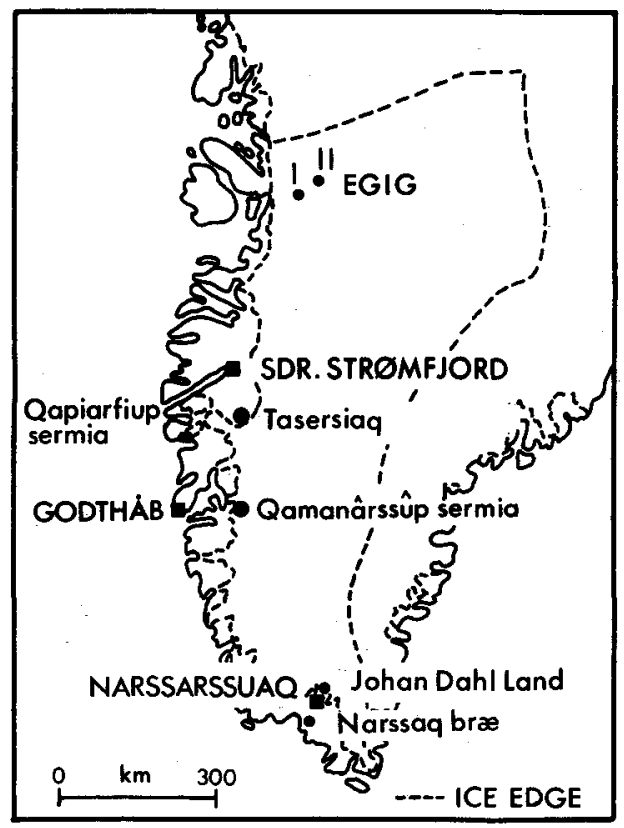

Fig. 1. Sketch map of West Greenland showing locations of GGU stations and the EGIG I (1959) and II (1967) camps (Ambach, 1963, 1977). Modified after Braithwaite \& Olesen (1982).

ation. If ice density measured every day is also taken into account, a significant correlation between net radiation and measured ablation is found, as internal ablation caused by penetration of shortwave radiation is important, e.g. some ablation occurs under the glacier surface during anticyclonic weather. Further investigations indicate that the easily measured elements, temperature, wind and their combinations, yield the only significant correlation with measured ablation.

\section{Qamanârssûp sermia 1984}

Energy balance measurements were carried out at about $625 \mathrm{~m}$ a.s.1. from June to August. The energy balance station was situated over ice, in a position about $3-4 \mathrm{~km}$ from the terminus where the glacier attains a width of $1 \mathrm{~km}$, and close to the centre line of ice movement. The area around the station appeared almost horizontal. Downstream from the station the surface was even and unbroken, but upstream it was dominated by minor ice ridges, perpendicular to the direction of ice movement. At about 700-800 m a.s.l. the glacier was heavily crevassed. Surface undulations and crevasses probably interfered with windflow, creating turbulence with winds draining downglacier. Incoming shortwave and net radiation were measured directly, and the turbulent flux of heat was calculated from measured vertical profiles of temperature and wind. Energy supply by condensation of moisture on the glacier surface and loss by conduction into the ice were treated as an aggregate residual term, deter- 
Table 1. The relative distribution of energy sources for ablation under different weather conditions in Johan Dahl Land 1981 and 1982

\begin{tabular}{|c|c|c|c|c|}
\hline Period & $\begin{array}{c}\text { Net } \\
\text { Radiation }\end{array}$ & $\begin{array}{c}\text { Sensible } \\
\text { heat }\end{array}$ & $\begin{array}{c}\text { Latent } \\
\text { heat }\end{array}$ & Weather conditions \\
\hline $22 / 7-23 / 7 / 81$ & 56 & 26 & 18 & Cyclonic \\
\hline $14 / 8-15 / 8 / 81$ & 30 & 51 & 19 & $\begin{array}{l}\text { Föhn succeeded by } \\
\text { precipitation }\end{array}$ \\
\hline $13 / 8-14 / 8 / 82$ & 88 & 12 & -23 & $\begin{array}{l}\text { Anticyclonic with } \\
\text { gravity winds }\end{array}$ \\
\hline $15 / 8-16 / 8 / 82$ & 100 & 0 & 0 & Anticyclonic, calm \\
\hline $22 / 7-20 / 8 / 81$ & 86 & 13 & 1 & Average \\
\hline $25 / 7-18 / 8 / 82$ & 96 & 4 & 0 & Average \\
\hline
\end{tabular}

Figures are percentages of measured ablation energy.

Modified after Ottosen (1986)

Table 2. The correlation coefficients between ablation and different climatic elements in Johan Dahl Land 1981 and 1982

\begin{tabular}{lcc}
\hline \multicolumn{1}{c}{ Element } & $\begin{array}{c}\text { Ablation } \\
1981\end{array}$ & $\begin{array}{c}\text { Ablation } \\
1982\end{array}$ \\
\hline Wind speed & $0.57 *$ & $0.61 *$ \\
Air temperature & $0.83 *$ & $0.83 *$ \\
Relative humidity & 0.17 & 0.20 \\
Net radiation & 0.01 & -0.15 \\
Shortwave radiation & -0.23 & -0.20 \\
\hline
\end{tabular}

* Correlation significant at $99 \%$ confidence level.

Modified after Ottosen (1986)

mined by subtracting the energy available as radiation and convection from the energy used for ablation at a stake close to the energy balance station.

Table 3 shows that radiative energy is the main source of ablation, providing two-thirds of the total energy received. This total covers large variations through the ablation period. In June radiation provided almost twice the energy used for melting, which means that the nonradiative terms were negative. As convection was positive through the entire ablation season, although varying with temperature and wind speed, energy was used for both evapor- 
Table 3. The distribution of radiative and non-radiative energy fluxes and energy used for ablation during seven selected periods at Qamanârssûp sermia in 1984.

\begin{tabular}{ccccc}
\hline Period & $\begin{array}{c}\text { Radiative } \\
\text { energy }\end{array}$ & $\begin{array}{c}\text { Non-radiative } \\
\text { energy }\end{array}$ & $\begin{array}{c}\text { Ablation } \\
\text { energy }\end{array}$ \\
\hline & & & & \\
I & $6 / 6-12 / 6 / 84$ & $8.3(193 \%)$ & $-4.0(-93 \%)$ & 4.3 \\
II & $13 / 6-26 / 6 / 84$ & $8.8(174 \%)$ & $-3.7(-74 \%)$ & 5.1 \\
III & $27 / 6-22 / 7 / 84$ & $10.0(62 \%)$ & $6.1(38 \%)$ & 16.1 \\
IV & $23 / 7-2 / 8 / 84$ & $7.5(38 \%)$ & $12.0(62 \%)$ & 19.5 \\
V & $3 / 8-6 / 8 / 84$ & $10.4(59 \%)$ & $7.2(41 \%)$ & 17.6 \\
VI & $6 / 8-13 / 8 / 84$ & $6.9(131 \%)$ & $-1.7(-31 \%)$ & 5.2 \\
VII & $14 / 8-25 / 8 / 84$ & $6.2(53 \%)$ & $5.6(47 \%)$ & 11.8 \\
& Weighted mean & $7.4(67 \%)$ & $3.7(33 \%)$ & 11.1 \\
\hline
\end{tabular}

Units are $\mathrm{MJ} \mathrm{m}^{-2} \mathrm{~d}^{-1}$

After Bendixen \& Knudsen (in press)

ation (with low values of humidity) and heating of the upper layers of ice. In July-August when cyclonic weather (including föhns) dominated, the situation changed so that $40-60 \%$ of the energy was provided by radiation.

\section{Qamanârssûp sermia 1986}

Improved instrumentation was planned for 1986 on the basis of earlier experience. Furthermore, it was desirable to locate the energy balance station in a part of the glacier which would be snow-covered at the beginning of the field season and would be without edge effects or large changes of surface topography. To make frequent adjustments of instrument heights to correct for the instrument masts sinking into the ice, which had earlier caused uncertainty in computing turbulent energy fluxes, good accessibility was needed. In May 1986 a position close to stake 93 (see fig. 2) which appeared to satisfy these criteria was selected by R. J. Braithwaite.

The station was located at $950 \mathrm{~m}$ a.s.1., about $900 \mathrm{~m}$ from the ice margin and $1 \mathrm{~km}$ below the place where Qamanârssûp sermia joins the Inland Ice. The glacier is $7-8 \mathrm{~km}$ wide at this level and is fairly flat with an average slope of 1:100 and without large crevasses. The nearby glacier-free terrain reaches about the same elevation as the ice surface and it is assumed that boundary effects are minimal. The station was established on a flat snow surface. Glacier ice prevailed beneath the instruments after 21 June, although a few periods (of 2-3 days) with snow cover occurred. Locally the surface slope fell $1-6^{\circ}$ towards the Inland Ice and increased $1-4^{\circ}$ downstream. In general, elongated rounded ice ridges, orientated longitudinally to the direction of ice movement with a topography of $20-50 \mathrm{~cm}$, dominated. The topography changed slightly from the beginning of the measuring period, but remained essentially unaltered as differences in levels were only augmented by $10-20 \mathrm{~cm}$.

The station is shown in fig. 3 and its lay-out in fig. 4. Temperature, wind velocity, and wind direction were measured using sensors that were read every ten minutes by twelve channel, 
Fig. 2. Sketch map showing the lower part of Qamanârssûp sermia. The energy balance station was located near stake 7 in 1984 and close to stake 93 in 1986. After Braithwaite (1983).

Fig. 3. Energy balance station at Qamanârssûp sermia in 1986 seen from $10^{\circ}$ east of north. Two white sheltered huts to the left contain the thermohygrographs and behind them a mast carries the radiation instruments. To the right there is a mast with shielded temperature sensors, anemometers and a wind direction sensor. Temperature and wind speed were measured at about $0.5,1.0$, $1.5,2.0,3.5$, and $5.0 \mathrm{~m}$ and wind direction at 2 and $5 \mathrm{~m}$.

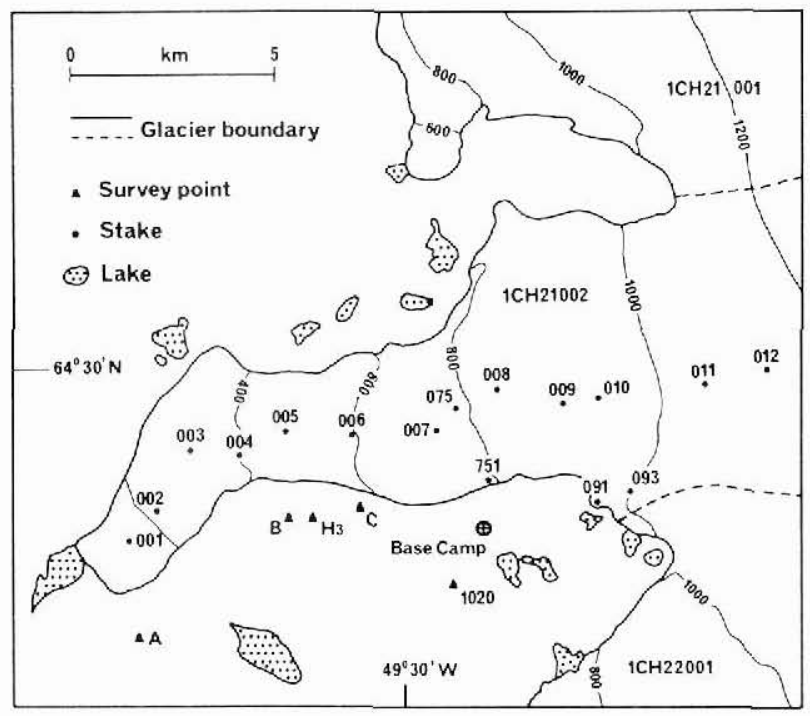

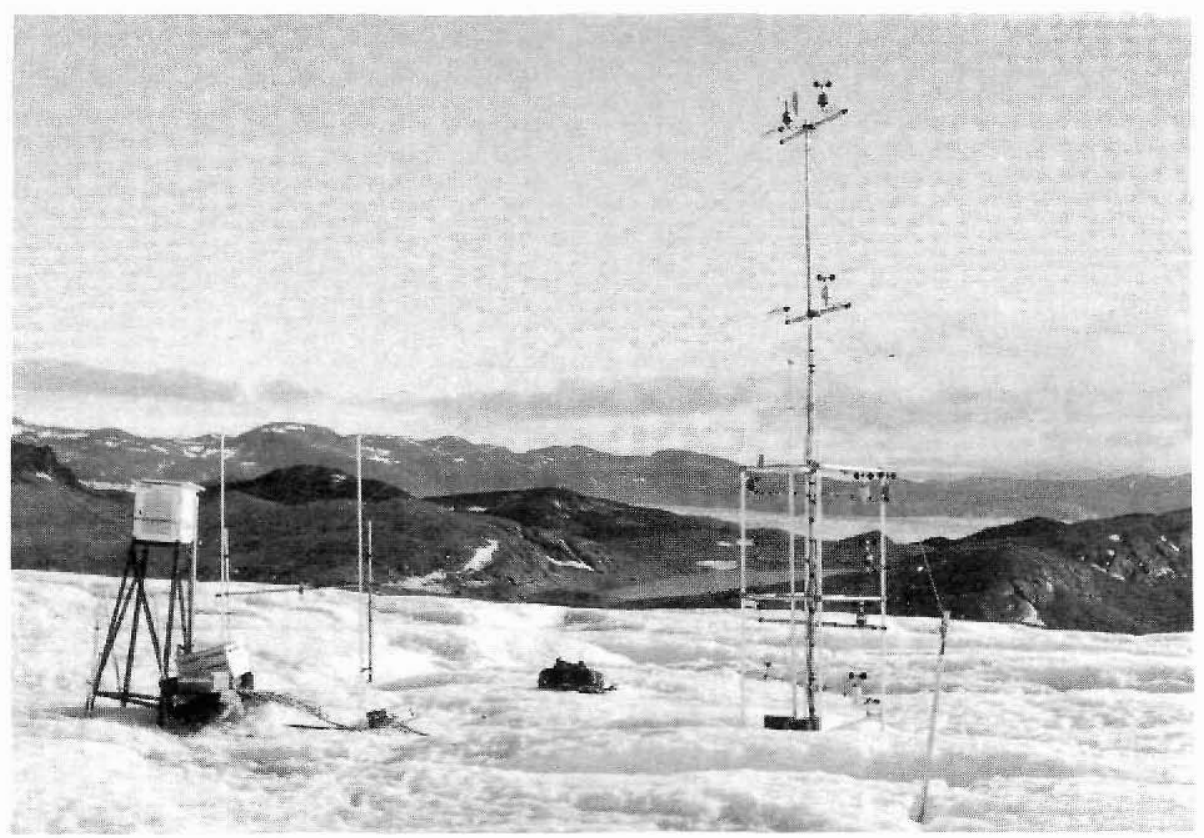




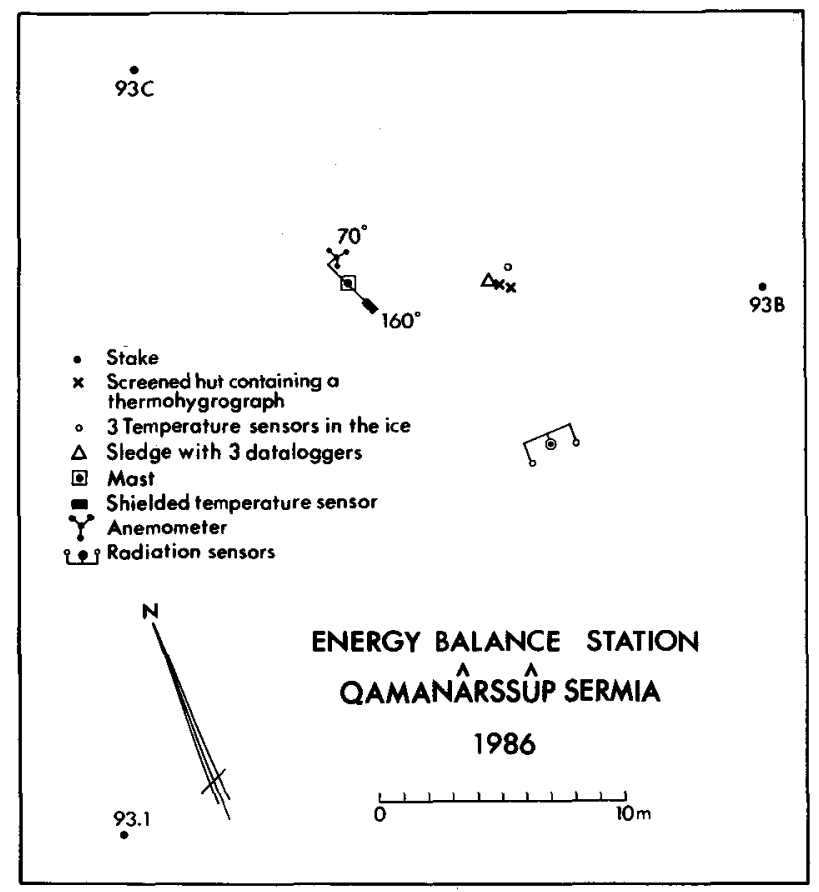

Fig. 4. Sketch map showing the lay-out of the energy balance station in 1986 .

battery-operated dataloggers. Three dataloggers were used, each placed on the ice in a heatinsulated box also containing a temperature sensor and a heating element.

Temperatures were recorded as instantaneous values, and wind speeds and directions as average values over the sampling period. Radiation measurements were recorded through millivolt integrators connected with a datalogger. Shortwave radiation components were measured with Kipp-Zonen pyranometers, and net radiation was measured with two polythene-shielded net radiometers of the Siemen-Ersking type. The air humidity was recorded by three thermohygrographs in sheltered huts, two at about $0.5 \mathrm{~m}$ above the ice surface and the third at $2 \mathrm{~m}$. Three temperature sensors were drilled into the ice at depths of 1.5, 2.5 and $3.5 \mathrm{~m}$ below the surface. Ablation was measured at three stakes (the ' 93 ' stakes) a total of 32 times, supplemented by measurements of ice density in August.

As radiation sensors were mounted on a separate mast to the temperature and wind sensors it was possible to avoid shadowing, and adjustments of instrument heights were easy. The radiation instruments were easily kept level whereas the mast with temperature and wind sensors inclined $3-5^{\circ}$ at times. As a rule, the heights of the different instruments needed adjustments of about $5 \mathrm{~cm}$ at each visit.

Data collection was from 10 June until 25 August, covering the main part of the ablation period. During the period, characteristic weather conditions such as sunny, calm weather, föhns, depression-dominated weather and snow storms occurred. 
The measurements at Qamanârssûp sermia in 1986 constitute one of the longest periods of energy-balance measurements on glaciers in West Greenland. A first evaluation of the data collected indicates that they are useful, although the datalogger sampling radiation failed for a four-day period. The location of the energy balance station and the frequent adjustments of instrument heights ensured a better determination of the sensible heat flux than previously. Together with detailed weather descriptions this will permit improved computation of the individual energy balance terms under different conditions. Having measured radiation with several instruments it is possible to determine a complete radiation balance and to analyse the variation of net radiation against measurement height and place. The methods used for measuring air humidity are inadequate and the results probably only indicate the order of magnitude of the condensation.

\section{Outlook}

So far, energy balance investigations (Ambach, 1963, 1977, 1985; Ottosen, 1986; Jensen, 1986; Bendixen \& Knudsen, unpublished data) carried out in West Greenland have thrown some light on the regional variations of energy balance. To gain more knowledge, it would be desirable to continue the energy balance project at other stations.

\section{References}

Ambach, W. 1963: Untersuchungen zum Energiumsatz in der Ablationszone des Grönländischen Inlandeises. Meddr Grønland, 174(4), $311 \mathrm{pp}$.

Ambach, W. 1977: Untersuchungen zum Energiumsatz in der Ablationszone des Grönländischen Inlandeises: Nachtrag. Meddr Grønland, 187(5), $63 \mathrm{pp.}$

Ambach, W. 1985: Characteristics of the heat balance of the Greenland ice sheet for modelling. J. Glaciol. 31, 3-12.

Bendixen, O. \& Knudsen, N. T.: Energy balance on Qamanârssûp sermia in the summer 1984. Unpublished manuscript.

Braithwaite, R. J. 1983: Glaciological and climatological investigations at Qamanârssûp sermia, West Greenland. Rapp. Grønlands geol. Unders. 115, 111-114.

Braithwaite, R. J. \& Olesen, O. B. 1982: Glaciological investigations at Qamanârssûp sermia. Field report 1979-1981 and appendix tables. Grønlands geol. Unders. Gletscher-hydrol. Meddr 82/2, 58 pp.

Jensen, J. P. 1986: En analyse af strålingsforhold og sammenhæng med ablation, Nordbogletscher, Sydgrønland. Specialerapport, Geologisk Institut, Aarhus Universitet, $81 \mathrm{pp}$.

Ottosen, O. 1986: Energibalancestudier på Nordbogletscher, Sydgrønland. Specialerapport, Geologisk Institut, Aarhus Universitet, $110 \mathrm{pp}$. 